\title{
ANALYSIS OF STUDENTS' VOCABULARY IN LEARNING ENGLISH
}

\author{
Ivan Susanto Salawazo ${ }^{1}$ \\ Universitas Prima Indonesia \\ Marintan Simbolon ${ }^{2}$ \\ Universitas Prima Indonesia \\ Vivi Enjelia Hutabarat ${ }^{3}$ \\ Universitas Prima Indonesia \\ Achida N. Veronika ${ }^{4}$ \\ Universitas Prima Indonesia \\ Erikson Saragih $^{5}$ \\ Universitas Prima Indonesia \\ ivansalawazo@gmail.com ${ }^{1}$
}

Submit, 11-12-2019 Accepted, 30-01-2020 Publish, 24-06-2020

\begin{abstract}
The purpose of this study was to analysis students' vocabulary in learning English of Ninth grade at SMP Swasta Yayasan Pangeran Antasari, Medan in the academic year of 2018/2019. The researchers used descriptive qualitative method to describe and implementing factual condition and characteristic. There are 72 students that decided two classes at ninth grade as the population. But the researcher only took one class consists of 36 students as the sample. To collecting data, researchers use questionnaire and vocabulary comprehension test as procedure. In analyzing the data, the researchers identifying the difficulties of students' vocabulary and cause difficulties by analyzing students answer sheets and their mistakes. There were 25 students (70\%) incorrect answer in the questions. There were 6 students $(16 \%)$ in modal, there were 8 students $(23 \%)$ in simple past tense, There were 8 students ( $24 \%$ ) in simple present tense, 3 students $(7 \%)$ troubled in simple continuous tense. Meaning. Students who gave incorrect answer in the questions were 29 students (82\%). Others difficulties is translation being other types of the questions that examined in this research. it was found that there were 23 students $(64 \%)$ who were unable to give the correct answer. Concluding the cause difficulties of students' vocabulary in learning English are the first students difficulties in pronouncing the words. Grammatical form be the second cause because the written form is different from the spoken form in english. The last, students does not give their attention to study english
\end{abstract}


more, knowing a words much more, and limitations their time to sources of information about new words vocabulary. The last, forgot the words easily.

Keywords : Analysis Students' Vocabulary, Difficulties, Cause

\section{INTRODUCTION}

Nowadays English most important for everybody because English is the international Language. Most people in many countries speak English for communicating with other people who are foreigners. Lowenberg (1991), in a discussion on the role of English as a foreign Language in Indonesia, suggest that because of the particular nature of the impact of English is making on the development and modernization of Indonesia's national Language, Bahasa Indonesia, English as an "additional" Language not merely as a "foreign" language. Consequently, English is essential for Indonesian students for the following three reasons : easy to find a high-quality job, communicating with International world, and accessing scientific sources in the students' major field.

In learning English, there are Language skills components and Language role that have to master. One of them is vocabulary. Vocabulary as one of the knowledge areas in Language, vocabulary is a great role for learners in acquiring a Language. Learners vocabulary development is an important aspect of their Language development. Vocabulary knowledge is more than just citing a word, it requires meaning based upon a given context and also often viewed as a critical tool for second language learners. Nation (2001) further describes the relationship between vocabulary use as complementary: knowledge of vocabulary enables Language use and, conversely, Language use leads to an increase in vocabulary knowledge. If student cannot master and learn more vocabulary, it is the problem and difficult for them to understand the Language especially learning to speak, listening, reading. In vocabulary to support their skills, they must to mastering that.

Vocabulary plays important role in Languange learning. Without sufficient vocabulary, people cannot express their ideas to communicate in form of spoken and written effectively. The more people master vocabulary the more they can speak, write, read, and listened as they want. Wilkins in thorn bury (2004) states that without grammar very little can to convey, without vocabulary nothing can to convey. It means that even someone has good grammar, but it will be useless if they do not know many vocabularies. The writer's experience while practice teaching in SMP Swasta Yayasan Pangeran Antasari, there were many students' problem, especially vocabulary and writing.

Vocabulary is the total number of words as people know and use it in their Language activities, a group of words and meaning to communicate with others as a main part of Language. Vocabulary is an essential subject to students to speak, 
read, write, and listen. Andriani \& Wahyuningsih (2019) found that students have a good ability in mastery vocabulary but have some difficulties also that related to the some aspects as grammar and spelling. Students still have many problems or difficulties in vocabulary mastery. Most of students have difficulties in grammar, how to understand the meaning of words, how to spell, and making translation (Rahman, 2016).

In this study, researcher analysis difficulties of students' vocabulary in learning English. On the results of previous research was found that students most difficulties in grammar, meaning, spelling, and translation. That results increase our knowledge and knew a case of learning english in vocabulary. But the results were not explained the basic part of students' difficulty in learning English. Thus, the researchers interested to research the difficulties of students' vocabulary in the same way, and explaining the basic problem students in learning English vocabulary.

\section{LITERATURE REVIEW}

Vocabulary is one of four skills in Language. Vocabulary is about words in a Language. According to Setiyaningsih (2009) vocabulary is all the words that is received by persons incidentally or Intentionally through indirect exposure to words explicitly instruction to specific word and word learning strategy. Vocabulary learning is essential part in foreign languange learning as the meanings of new words are very often emphasized. On the other hand vocabulary is the knowledge of english Language as L2 learners' greatest single sources (Muara, 1980).

Learning vocabulary represents one of most important skill and necessary for learning English Language. The talk about the improtance of vocabulary is related To communicate with other people using a language, so here we have to mastered in vocabulary. Vocabulary is the total number of words Language which supports the speaker in communication. In other words, vocabulary plays as central to English Language teaching to develop the Language skill. Without a lot of vocabulary students cannot understand others or express their ideas. Vocabulary is the total number of words. According to Napa (1991) vocabulary is one of the Language components. Jarpersen (2007) defines that vocabulary is words formation by means of suffixes and prefixes. In vocabulary, students order to have a lot learn of vocabularies to make easily to speak, write, read, and listened. When students start to learn English Language, students have to acquire about the vocabulary of the Language. It is beginning process for students learn a unit of words presented by theteachers. Thornburg (2002) state: there are two steps for vocabulary practice. They are: 
1. Learner training. In learner training there are five activities that can use, they are: a) they pay attention to form, b) they pay attention to the meaning, c) they are a good guesser, d) they encourage to take risks and not afraid to making mistakes, e) they know how to organize their own learning, like using dictionaries to know the meaning of words in Language

2. Word games (Thornbury, 2002). Word games can use in teaching vocabulary by using categories of word. For example, the topic is animal.

From the explanation above the writers conclude that vocabulary has so many words it will difficult to understand if the people did not know about the function of it. It realized that to express something we need more than one word to make people understand and to make the sentences clear in the language learning of vocabulary. Studying a Language cannot be separated from studying vocabulary because when we are learning speaking, reading listening and writing we all need vocabulary which is the knowledge of meaning is one of the components of a language.

From the statements above, the writers comes to an perceptions that the vocabulary the important role to increase the students' ability in the developing of teaching and learning, so the teacher should be taught vocabulary to the student since the students young so that the learner will easy to master vocabulary and they can reach the goals of teaching and learning a foreign Language, that is produce a Language in speaking, reading, and writing.

\section{RESEARCH METHOD}

In this research, researchers use descriptive qualitative method. This method is attempt to describe and implementing factual condition and characteristic of a case study in which the researchers investigating the difficulties students' vocabulary and causes difficulties students' vocabulary in learning English. The population of this research is at Ninth grade of SMP Swasta Yayasan Pangeran Antasari. There are 72 students that devided two classes. But the researcher only take one class that consists of 36 students as the sample.

The data collecting procedure that use in this research are questionnaire and vocabulary comprehension test. Both of questionnaire and vocabulary comprehension test to know kind and cause difficulties of students' vocabulary in learning English.

1. Vocabulary comprehension test. For the questions consists of 40 questions. Two kinds of vocabulary test that researchers give to the student are : a) multiple choice : consists of 25 questions, b) match the words : consists of 10 questions. 
2. Questionnaire. The questionnaire present in Indonesia Language so that respondents could quickly fill out the response in 10 minutes. The questionnaire consist of 5 questions for gathering information from respondents.

Table 1. Qualification Categories of Student's Ability in Mastering Vocabulary

\begin{tabular}{lll}
\hline No & Range & Category \\
\hline 1 & $81-100$ & Very good \\
\hline 2 & $70-79$ & Good \\
\hline 3 & $56-69$ & Fair \\
\hline 4 & $46-55$ & Poor \\
\hline 5 & $0-45$ & Very poor \\
\hline
\end{tabular}

Buku Model Penilaian Kelas KBK (BSNP) 2007

The first, Identifying the difficulties of student vocabulary by analyzing students answer sheets and their mistakes. After identifying, researchers classifying the difficulties of students' vocabulary based on their answer sheets and their mistakes.

\section{FINDINGS}

The first, researchers provided the results of data analysis based on vocabulary comprehension test. Grammar the main focus researcher in test of vocabulary comprehension. The question which contain modal verb consists of 4 questions. There was found that 5 students gave incorrect answer. simple past tense consists 10 questions that 8 students difficulties to answer questions. simple present tense 8 students that also gave incorrect answer that consists of 10 questions. present continuous tense that consists of 10 questions was found 3 students incorrect answer. Next, question form is about meaning that consists of 6 questions were found that 29 students did mistakes and gave inccorect answer.

Next, provided the results of data based on questionnaire. This question consists of 10 questions.

1. Do you like study English (apakah kamu suka belajar bahasa Inggris)? Yes or no. Explain? Only 15 students answer yes. Their reason is because English is good for future. Another students were no. The reason is because the do not know anything about english

2. Do you have problem in vocabulary ( apakah kamu ada kesulitan dalam kosakata)? yes or no. Explain! For this question, students as much $90 \%$ answer yes. Most of Their reasons is because they "lazy to study english". It means that is the maint point that researchers got the difficulties of students to learn English. 
3. Do you have problem in pronouncing words ( apakah kamu ada kesulitan dalam mengucapkan kosakata)? Yes or no. Explain!For this question, almost all students answers yes because different from Indonesia Languange words to pronouncing.

4. Do you have problem in translating words? Yes or no. Explain! Their answer is yes. Because they have limited of vocabulary.

5. Is vocabulary important to learn english ( apakah kosakata penting dalam belajar bahasa Inggris)? Yes or no. Explain? All of students answers yes. Most their reason is because vocabulary is important to speak and making sentence

\section{DISCUSSION}

The first, researcher identify students difficulties in vocabulary mastery by analyzed students' answer sheets then analyzing students' false answer. Researchers provided the data based on the results of students' ability in vocabulary mastery based on vocabulary comprehension test. Grammar In this result show there were 25 students $(70 \%)$ who gave incorrect answer in question. Who gave incorrect answer related the type of verb followed by modal, There were 6 students $(16 \%)$. Next, there were 8 students $(23 \%)$ have difficulties in simple past tense. There were 8 students $(24 \%)$ have troubles in answering questions type of verbs used in simple present tense. The last, there were 3 students $(7 \%)$ troubled to decide the type of verb used in present continuous tense. Meaning There are many students did mistake to answer the questions. Students who gave incorrect answer in the questions were 29 students (82\%). There were incorrect in parts of verbs to acquire the correct meaning, noun to proper meaning, and noun for appropriate meaning. Other difficulties it was found there were 23 students (64\%) who were unable to provide the correct answer the types of question about translation. According to Stepherd (Gazlianty, 2011) explains one of the criteria of vocabulary mastery that the students are able to use them in appropriate grammatical form.

Based on the result, of data analysis questionnaire, the researchers was found that lack of student interest to learning vocabulary English. Pronouncing The differences between spoken and written in English was become the factor of difficulties of students to learning English. For example, when the students faced the words muscle, listen, write, honestly, judge, science. Some words that contain problematic especially Indonesia students. Grammatical The written form is different from the spoken form in English. When the students want to write a word, "muscle" and "science," they just write the word that heard "massel", " sains". That sign that cause difficult of students to learn english vocabulary. Because that is influence their English skills. Forget the words easily the number of words that students need to learn is exceedingly large. The limitations of sources of information about words. Because generally many students does not 
give their attention more and inserted to learn English. The last cause is because students have limitations vocabulary, so they difficult to translating words.

\section{CONCLUSION}

Based of the results of data analysis the difficulties of students' vocabulary and causes difficulties of students' vocabulary in learning English, researchers can summary. The findings of this study shows that the difficulties of students' vocabulary was found in grammar. There were students incorrect answer in the questions, in modal, simple past tense, in simple present tense, in simple continuous tense, and In Meaning. Others difficulties Translation being other types of the questions that examined in this research. it was found that students unable to provide the correct answer. Based on the results and the data analysis, researchers concluding the cause difficulties of students' vocabulary in learning English are the first students difficulties in pronouncing the words Grammatical form be the second causes because the written form is different from the spoken form in English. The last is students forget the easily because most students does not give their attention to study english more, knowing a words much more, and limitations their time to the source of information about new words vocabulary

\section{REFFERENCES}

Andriani, D., \& Sriwahyuningsih, V. (2019). An Analysis of Students' Mastery of Vocabulary. Universitas Putra Indonesia YPTK Padang. ELTLectura, 6(2), 169-176.

Gazlianty. (2011). Improving Vocabulary Skill by Using Puzzle Game: A ClassAction Research at Second Grade of SMAN 1 Narmada. Unpublished Thesis.

Jarperson. (2007). Word Formation: Prefixes and suffixes. Journal of Student Vocabulary, 22(1), 71-97.

Lowenberg. (1991). English as a Foreign Languange in Indonesia. Word Englishes, 10(3), 133-145

Muara. (1980). Grammar and Vocabulary Mastery on Students' Reading Comprehension. ReadingResearch Quarterly, 20(2), 522-535.

Napa. (1991). Vocabulary Learning and Teaching. Boston, MA: Heinle \& Heinle.

Nation. (2001). Principle of Language Learning and Teaching Vocabulary. New Jersey: Prentice Hall Inc.

Rahman, F. (2016). An Analysis of Students' Difficulties in Vocabulary Mastery. University of Mataram. Journal. 4(2), 115- 119

Setiyaningsih. (2009). Practising Maritime English Vocabulary and Developing through the Wall Dictation, 3(2), 72-74.

Thornbury, S. (2002). How to Teach Vocabulary. London: Longman

Wilkins, T. (2004). How to Teach Vocabulary. England: Pearson Education Limited. 